Supplemental Material

\title{
Modulation of zircon solubility by crystal-melt dynamics
}

Dawid Szymanowski, Francesca Forni, John A. Wolff, Ben S. Ellis

\section{Additional background on eruptive units featured in Fig. 3.}

\section{Campanian Ignimbrite, Campi Flegrei, Italy}

The Campanian Ignimbrite $\left({ }^{40} \mathrm{Ar} /{ }^{39} \mathrm{Ar}\right.$ age $~ 39 \mathrm{ka}$, De Vivo et al., 2001; (U-Th)/He

age $\sim 42 \mathrm{ka}$, Gebauer et al., 2014), erupted from the Campi Flegrei caldera (southern Italy), is a zoned pyroclastic sequence $\left(\sim 200 \mathrm{~km}^{3} \mathrm{DRE}\right)$ characterized by remarkable compositional, crystallinity and thermal gradients (Civetta et al., 1997; Pappalardo et al., 2008). The zoning pattern of the Campanian Ignimbrite has been interpreted as a result of fractional crystallization processes involving mostly feldspars with minor amounts of clinopyroxene, biotite, oxides and apatite, leading to the development of a crystal mush from which crystal-poor, more evolved and buoyant melts were efficiently extracted and erupted first (Forni et al., 2016). The crystalrich, mushy portions of the reservoir were remobilized upon recharge of hotter, more mafic melts and occur only in the upper portion of the pyroclastic sequence (Forni et al., 2016). While the crystal-poor units display relatively low $\mathrm{Ba}, \mathrm{Sr}$ and negative $\mathrm{Eu}$ anomalies indicative of feldspar fractionation, the crystal-rich portions show remarkable enrichments in $\mathrm{Sr}$, Ba together with positive Eu anomalies, characteristic of feldspar accumulation. $\mathrm{Ba}$ and $\mathrm{Sr}$-rich rims of feldspars and positive Eu anomalies in outermost zones of clinopyroxenes indicate pre-eruptive crystal growth from a liquid derived by partial melting of a feldspar- and biotitebearing crystal mush (Forni et al., 2016). The modeling of cumulate compositions in Fig. 3 was performed using phase proportions from Pappalardo et al. (2008) with mineral compositions varying within the ranges reported by Forni et al. (2016).

\section{Carpenter Ridge Tuff, Southern Rocky Mountain volcanic field, Colorado, USA}

The Carpenter Ridge Tuff, erupted from the central cluster of the Southern Rocky Mountain volcanic field in Colorado, is a voluminous ignimbrite $(\sim 1000$ $\mathrm{km}^{3} \mathrm{DRE}$ ) dated at $27.55 \mathrm{Ma}$ and associated with the formation of the Bachelor caldera (Lipman and McIntosh, 2008). The Carpenter Ridge Tuff is a linearly 
zoned pyroclastic sequence, mostly consisting of crystal-poor rhyolites which transition towards crystal-rich trachydacites at the top (Bachmann et al., 2014). The trachydacitic fiamme are characterized by extreme enrichments in $\mathrm{Ba}, \mathrm{Zr}$, $\mathrm{Sr}$, positive Eu anomalies, and elevated $\mathrm{Fe}-\mathrm{Ti}$ oxide temperatures. They also typically contain resorbed mineral phases (feldspars and biotite) overgrown by high-Sr-Ba rims (Bachmann et al., 2014). The enrichments have been interpreted as representing recharge-induced melting of near-solidus crystal mush, whereby feldspar- and biotite-compatible elements (particularly $\mathrm{Ba}$ ) become enriched in the cumulate melt relative to the evolved rhyolite represented in the earlyerupted material (Bachmann et al., 2014). Both the rhyolite and the trachydacitic fiamme have the same mineral assemblage of plagioclase, sanidine, biotite, $\mathrm{Fe}-\mathrm{Ti}$ oxides, rare amphibole and pyroxene, and zircon. The modeling in Fig. 3 used phase proportions based on the estimates by Bachmann et al. (2014) including assemblages with variable quartz content, and measured mineral compositions from Bachmann et al. (2014) and Whitney et al. (1988).

\section{Rhyolites of Lipari, Aeolian Islands, Italy}

Over the last $\sim 267 \mathrm{ky}$, the island of Lipari has erupted lavas and pyroclastic rocks ranging in composition from basaltic andesites to rhyolites with a compositional gap in the dacitic field. Basaltic-andesitic to andesitic magmas dominated until $81 \mathrm{ka}$, whereas rhyolitic volcanism started at $43 \mathrm{ka}$, when the volcanic activity resumed after a $\sim 40$ ky-long period of quiescence, and proceeded until historical times (Forni et al., 2013). Geochemical and isotopic data indicate that the rhyolitic magmas were generated via fractional crystallization (with minor crustal assimilation) from more mafic parental melts akin to Lipari andesites (Forni et al., 2015). The rhyolitic magmas are typically crystal-poor and contain latitic to trachytic crystal-rich enclaves with a mineralogy of plagioclase, clinopyroxene, olivine, sanidine, biotite, $\mathrm{Fe}$-Ti oxides, apatite and zircon. The cumulate signatures of the enclaves (i.e., enrichments in $\mathrm{K}_{2} \mathrm{O}, \mathrm{Sr}, \mathrm{Ba}$ ) indicate that the they represent crystalline portions of the magmatic reservoir left over after rhyolite generation rather than alkaline magmas mixed with the rhyolites as previously hypothesized (Davì et al., 2010; Gioncada et al., 2003, 2005). The occurrence of resorbed feldspar, clinopyroxene and biotite within the enclaves suggests that hotter, more mafic recharge magma likely triggered partial melting and cumulate remobilization (Forni et al., 2015). In Fig. 3, cumulate compositions are represented by bulk-rock compositions of the enclaves whereas cumulate melts are represented by their groundmass, as reported by Forni et al. (2015). Additionally, bulk compositions of two samples of mingled rhyolite can be shown to represent mingling of the dominant rhyolite with a $\mathrm{Ba}$, Sr-enriched cumulate melt (Forni et al., 2015). 


\section{MELTS modeling of cumulate melting}

Thermodynamic modeling of phase equilibria in cumulate melting scenarios (Fig. 3) was performed with rhyolite-MELTS v.1.0.2 (Gualda et al., 2012). The starting material was a simulated bulk crystal mush composition calculated by mixing the model cumulate solid composition (brown-grey in Fig. 3) with the respective extracted melt composition (red in Fig. 3) in weight proportions of 80/20, which simulates a resident crystal mush with $20 \%$ interstitial liquid. Phase equilibria during cumulate melting could then be explored in reverse by bringing this composition to liquidus and subsequent cooling in $1{ }^{\circ} \mathrm{C}$ temperature steps, at fixed pressure of 2.5 kbar (Campanian Ignimbrite; Fowler et al., 2007) and 2 kbar (Carpenter Ridge Tuff; Whitney et al., 1988 and Lipari; De Rosa et al., 2003), 3 wt\% initial $\mathrm{H}_{2} \mathrm{O}$ and oxygen fugacity of QFM+1. The calculations were performed in equilibrium crystallization mode. The MELTS output of major element compositions of the melt as a function of temperature was then used to calculate $M$ and $\mathrm{Zr}$ solubility at every temperature step using the model of Watson and Harrison (1983). $\mathrm{Zr}$ contents in melts were modeled with the equilibrium crystallization equation using initial $\mathrm{Zr}$ contents as given by the 80/20 mix above and $\mathrm{Zr}$ partition coefficients for all crystallized mineral phases from the GERM database (www.earthref.org/KDD).

In each case, we evaluated the compositional trajectory of liquids as cumulate minerals get progressively destabilized, from $20 \%$ melt (whose composition should approximate the initial interstitial melt) to $100 \%$ melt for complete melting of the cumulate mush. Two main features of the MELTS trajectories are observed.

(1) For zircon-undersaturated melt compositions (black), resorption of Zr-poor major mineral phases dilutes the $\mathrm{Zr}$ content of the melt as 'cumulate melting' progresses. (2) If the initial $\mathrm{Zr}$ in melt is high, the first melts will be zircon-saturated (green); in this case the increase in temperature as melting progresses results in increasing $\mathrm{Zr}$ solubility. Here, $\mathrm{Zr}$ in melt will follow the $\mathrm{Zr}$ solubility limit, to a point where solubility exceeds $\mathrm{Zr}$ in melt given by partitioning.

\section{Campanian Ignimbrite}

Cumulate melting in the Campanian Ignimbrite magma system (Fig. 3A) results in melts that are initially zircon-undersaturated and become severely diluted in $\mathrm{Zr}$ as a result of adding a zircon-free, feldspar-rich mineral assemblage. Most melt evolution occurs along a trajectory from the first melts towards a $\sim$ pure alkali feldspar component ( $M=1.7, \mathrm{Zr}=0$; see Wolff, 2017 for a detailed discussion). It is only when feldspars are exhausted at $\sim 900{ }^{\circ} \mathrm{C}$ (85\% melt) that $M$ becomes strongly controlled by clinopyroxene and magnetite and increases substantially. The compositions of the observed cumulate melts can be reproduced at $\sim 70 \%$ melt and 
temperatures between $\sim 880$ and $890^{\circ} \mathrm{C}$. However, the model is fairly sensitive to the choice of the initial mix (and consequently the $\mathrm{Zr}$ content) and can fit the data over a wide range of melt contents.

\section{Carpenter Ridge Tuff}

Carpenter Ridge Tuff cumulate melting (Fig. 3B) occurs entirely in the zircon saturated field. Cumulates here are zircon-bearing and so their $\mathrm{Zr}$ content is difficult to estimate (chosen value was $1000 \mathrm{ppm}$ ); however, the model is insensitive to this parameter. For most reasonable cumulate $\mathrm{Zr}$ concentrations, all generated cumulate melts are zircon-saturated, so their $\mathrm{Zr}$ content is controlled entirely by $\mathrm{Zr}$ solubility. The first liquids appear near the extracted melt composition and initially evolve towards low $M$ as the eutectic phase assemblage of two feldspars and quartz is added back to the melt. At the point of sanidine and quartz exhaustion (55\% melt), the melt leaves the eutectic; the increase in temperature from this point monotonously increases the amount of $\mathrm{Zr}$ dissolved in the melt. $M$ varies little as it is controlled by plagioclase with minor biotite, magnetite and ilmenite. The best fit to the observed cumulate melt compositions is around $900{ }^{\circ} \mathrm{C}$ which corresponds in our model to $85 \%$ melt. This temperature is in excellent agreement with the findings of Whitney et al. (1988) and Bachmann et al. (2014) who found Fe-Ti oxide and amphibole temperatures of $850-1000^{\circ} \mathrm{C}$ for the trachydacite fiamme representing the cumulate melts.

\section{Lipari}

In the model for Lipari rhyolites (Fig. 3C) both zircon-saturated and -undersaturated behavior is observed. The Lipari cumulates contain $\sim 185 \mathrm{ppm}$ $\mathrm{Zr}$, and as a result the starting mix has $177 \mathrm{ppm} \mathrm{Zr}$. The initial melts are zirconsaturated and remain so until $\sim 800{ }^{\circ} \mathrm{C}(53 \%$ melt) where the increase in solubility outpaces $\mathrm{Zr}$ enrichment in the melt. Following that, the trajectory is dominated by feldspar and biotite resorption. At $\sim 915{ }^{\circ} \mathrm{C}$ ( $85 \%$ melt) last plagioclase is exhausted which results in a sharp turn and increase in $M$ at relatively invariable $\mathrm{Zr}$ towards the highest melt contents. According to the MELTS model, the observed Lipari cumulate melt compositions can be reproduced both at low ( 15-20\%) and high ( 90\%) amounts of melting. The occurrence of zircon (together with feldspars and biotite) in Lipari enclaves suggests that low degrees of melting under zircon saturation represent a plausible scenario for cumulate melting in Lipari's mush. 


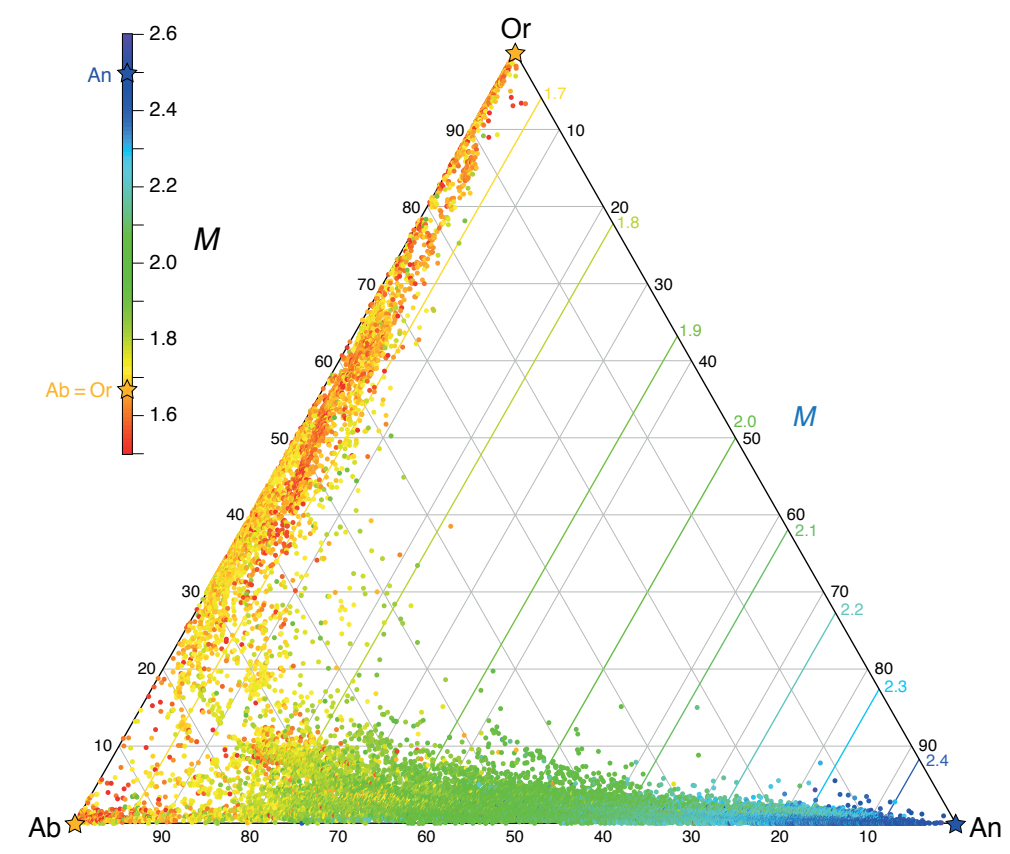

Fig. S1 Variability of $M$ values in magmatic feldspars. In stoichiometric feldspars composed of $\mathrm{Na}, \mathrm{K}, \mathrm{Ca}, \mathrm{Al}$ and Si, M varies from 1.67 for compositions on the albite-orthoclase join to 2.5 for pure anorthite (colored contours). Natural feldspar analyses (color-coded points) extracted from the GEOROC database (access July 2019, $\mathrm{n}$ 34,000) show minor deviations from the idealized contours as a result of minor cation contents and analytical scatter.
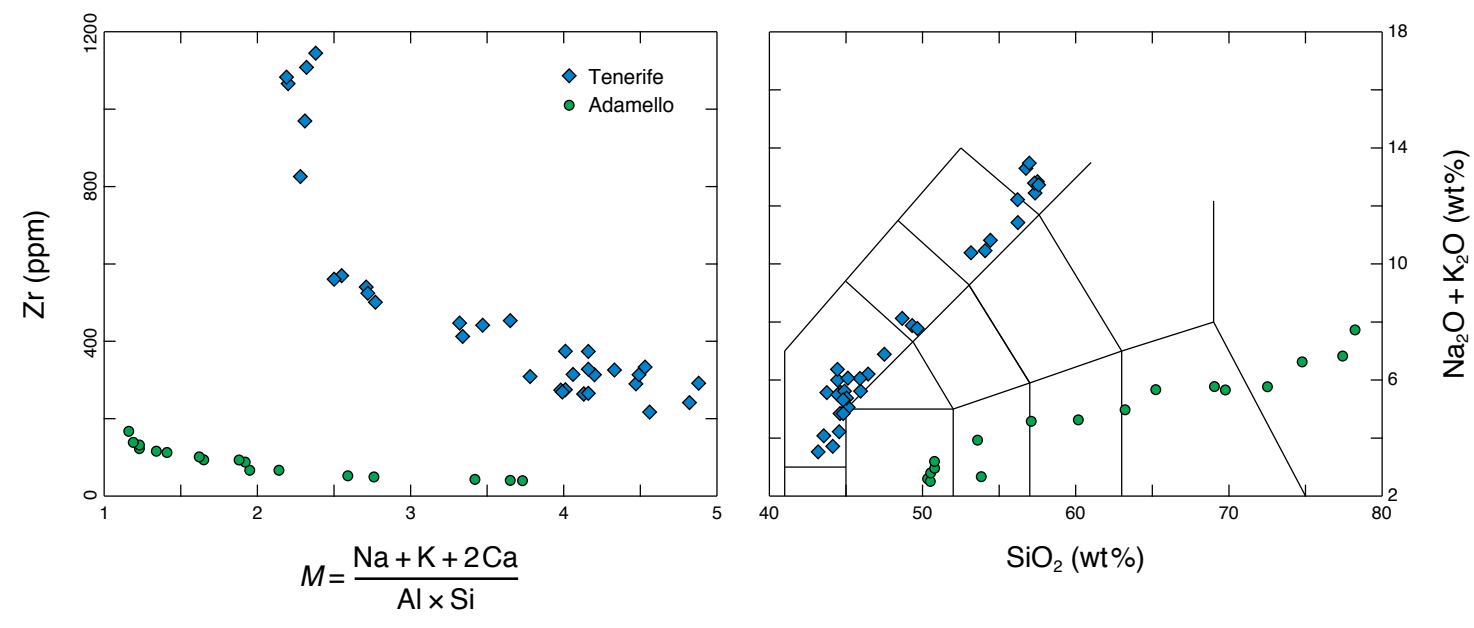

Fig. S2 Evolution of $\mathrm{M}-\mathrm{Zr}$ in two magma compositional series representative of the alkaline (Diego Hernández Formation, Tenerife, Canary Islands) and calc-alkaline (Adamello batholith, southern Alps, Italy) liquid line of descent. Tenerife data are whole-rock compositions from Wolff et al. (2000) and Edgar et al. (2002) screened for mixing, alkali loss and cumulate melting (high $\mathrm{Ba}$ ). 'Adamello' data are compositions of melt in $0.7 \mathrm{GPa}$ fractional crystallization experiments of Nandedkar et al. (2014) with starting materials equivalent to primitive Adamello batholith compositions; $\mathrm{Zr}$ contents are modeled using the equilibrium crystallization equation and parametrizations of $\mathrm{Zr}$-melt partition coefficients from Marxer and Ulmer (2019). 


\section{References cited}

Bachmann, O., Deering, C.D., Lipman, P.W., and Plummer, C., 2014, Building zoned ignimbrites by recycling silicic cumulates: insight from the $1,000 \mathrm{~km}^{3}$ Carpenter Ridge Tuff, CO: Contributions to Mineralogy and Petrology, v. 167, p. 1-13.

Civetta, L., Orsi, G., Pappalardo, L., Fisher, R. V., Heiken, G., and Ort, M., 1997, Geochemical zoning, mingling, eruptive dynamics and depositional processes - The Campanian Ignimbrite, Campi Flegrei caldera, Italy: Journal of Volcanology and Geothermal Research, v. 75, no. 3-4, p. 183-219.

Davì, M., De Rosa, R., and Holtz, F., 2010, Mafic enclaves in the rhyolitic products of Lipari historical eruptions; relationships with the coeval Vulcano magmas (Aeolian Islands, Italy): Bulletin of Volcanology, v. 72, no. 8, p. 991-1008.

De Rosa, R., Donato, P., Gioncada, A., Masetti, M., and Santacroce, R., 2003, The Monte Guardia eruption (Lipari, Aeolian Islands): an example of a reversely zoned magma mixing sequence: Bulletin of Volcanology, v. 65, no. 7, p. 530-543.

De Vivo, B., Rolandi, G., Gans, P.B., Calvert, A., Bohrson, W. A., Spera, F. J., and Belkin, H.E., 2001, New constraints on the pyroclastic eruptive history of the Campanian volcanic Plain (Italy): Mineralogy and Petrology, v. 73, no. 1-3, p. 47-65.

Edgar, C.J., Wolff, J.A., Nichols, H.J., Cas, R.A.F., and Martí, J., 2002, A complex Quaternary ignimbrite-forming phonolitic eruption: the Poris Member of the Diego Hernández Formation (Tenerife, Canary Islands): Journal of Volcanology and Geothermal Research, v. 118 , p. 99-130.

Forni, F., Bachmann, O., Mollo, S., De Astis, G., Gelman, S.E., and Ellis, B.S., 2016, The origin of a zoned ignimbrite: Insights into the Campanian Ignimbrite magma chamber (Campi Flegrei, Italy): Earth and Planetary Science Letters, v. 449, p. 259-271.

Forni, F., Ellis, B.S., Bachmann, O., Lucchi, F., Tranne, C.A., Agostini, S., and Dallai, L., 2015, Erupted cumulate fragments in rhyolites from Lipari (Aeolian Islands): Contributions to Mineralogy and Petrology, v. 170, no. 5-6, p. 1-18.
Forni, F., Lucchi, F., Peccerillo, A., Tranne, C. A. Rossi, P. L., and Frezzotti, M. L., 2013, Stratigraphy and geological evolution of the Lipari volcanic complex (central Aeolian archipelago), in: Lucchi, F., Peccerillo, A., Keller, J., Tranne, C.A., and Rossi, P.L., eds., The Aeolian Islands Volcanoes: Geological Society, London, Memoir 37, p. 213-279.

Fowler, S. J., Spera, F., Bohrson, W., Belkin, H. E., and De Vivo, B., 2007, Phase equilibria constraints on the chemical and physical evolution of the campanian ignimbrite: Journal of Petrology, v. 48, no. 3, p. 459-493.

Gebauer, S.K., Schmitt, A.K., Pappalardo, L., Stockli, D. F., and Lovera, O. M., 2014, Crystallization and eruption ages of Breccia $\mathrm{Mu}$ seo (Campi Flegrei caldera, Italy) plutonic clasts and their relation to the Campanian ignimbrite: Contributions to Mineralogy and Petrology, v. 167, no. 1, p. 1-18.

Gioncada, A., Mazzuoli, R., Bisson, M., and Pareschi, M. T., 2003, Petrology of volcanic products younger than $42 \mathrm{ka}$ on the LipariVulcano complex (Aeolian Islands, Italy): an example of volcanism controlled by tectonics: Journal of Volcanology and Geothermal Research, v. 122, no. 3-4, p. 191-220.

Gioncada, A., Mazzuoli, R., and Milton, A.J., 2005, Magma mixing at Lipari (Aeolian Islands, Italy): Insights from textural and compositional features of phenocrysts: Journal of Volcanology and Geothermal Research, v. 145 , no. 1-2, p. 97-118.

Gualda, G. A. R., Ghiorso, M. S., Lemons, R. V., and Carley, T. L., 2012, Rhyolite-MELTS: a modified calibration of MELTS optimized for silica-rich, fluid-bearing magmatic systems: Journal of Petrology, v. 53, no. 5, p. 875-890.

Lipman, P. W., and McIntosh, W.C., 2008, Eruptive and noneruptive calderas, northeastern San Juan Mountains, Colorado: Where did the ignimbrites come from?: Geological Society of America Bulletin, v. 120, no. 7-8, p. 771-795.

Marxer, F., and Ulmer, P., 2019, Crystallisation and zircon saturation of calc-alkaline tonalite from the Adamello Batholith at upper crustal conditions: an experimental study: Contributions to Mineralogy and Petrology, v. 174, 84. 
Nandedkar, R.H., Ulmer, P., and Müntener, O., 2014, Fractional crystallization of primitive, hydrous arc magmas: an experimental study at $0.7 \mathrm{GPa}$ : Contributions to Mineralogy and Petrology, v. 167, 1015.

Pappalardo, L., Ottolini, L., and Mastrolorenzo, G., 2008, The Campanian Ignimbrite (southern Italy) geochemical zoning: insight on the generation of a super-eruption from catastrophic differentiation and fast withdrawal: Contributions to Mineralogy and Petrology, v. 156, p. 1-26.

Watson, E. B., and Harrison, T. M., 1983, Zircon saturation revisited: temperature and composition effects in a variety of crustal magma types: Earth and Planetary Science Letters, v. 64, no. 2, p. 295-304.
Whitney, J. A., Dorais, M. J., Stormer, J. C., Kline, S. W., and Matty, D. J., 1988, Magmatic conditions and development of chemical zonation in the Carpenter Ridge Tuff, central San Juan volcanic field, Colorado: American Journal of Science, v. 288, p. 16-44.

Wolff, J.A., 2017, On the syenite-trachyte problem: Geology, v. 45, p. 1067-1070.

Wolff, J.A., Grandy, J.S., and Larson, P.B., 2000, Interaction of mantle-derived magma with island crust? Trace element and oxygen isotope data from the Diego Hernandez Formation, Las Cañadas, Tenerife: Journal of Volcanology and Geothermal Research, v. 103, p. 343-366. 